Acta vet. scand. $1973,14,450-463$.

From the FAO/WHO International Reference Centre for Animal Mycoplasmas, Institute of Medical Microbiology, University of Aarhus, Denmark.

\title{
BOVINE MYCOPLASMAS: CULTURAL AND BIOCHEMICAL STUDIES \\ II
}

By

H. Ern $\phi$ and L. Stipkovits *

ERNØ, H. and L. STIPKOVITS: Bovine mycoplasmas: Cultural and biochemical studies. II. Acta vet. scand. 1973, 14, 450-463. - A number of biochemical and biological tests have been performed using reference strains of presently known mycoplasma species or serogroups of bovine origin. The purpose of these investigations was partly to fulfil the requirements of "The Subcommittee on the Taxonomy of Mycoplasmatales" in describing new species of mycoplasmas, and partly to select methods which might be of value in daily diagnostic work. Concerning the latter point, the following tests are recommended for strains belonging to the digitonin resistant genus Acholeplasma: catabolism of galactose, xylose, aesculin and arbutin. In the genus Mycoplasma, which is digitonin sensitive, 5 tests are of special value: catabolism of glucose and arginine, phosphatase activity, formation of "film and spots", and serum digestion.

bovine mycoplasmas; biochemical characteri z a tion.

In a previous paper (Ernф $\&$ Stipkovits 1973 ) reference was made to methods recommendable for cultivation of mycoplasmas of bovine source. Studies of representative strains of 15 bovine and 2 ovine species or serogroups were accomplished to the point of classification into family (genus). Members of the genus Acholeplasma are digitonin resistant, while members of genus Mycoplasma are digitonin sensitive. The present work deals with a number of biochemical and biological tests helpful for classifioation into species.

* WHO Junior Research Fellow. Present address: Veterinary Medical Research Institute, Hungarian Academy of Sciences, Budapest XIV, Hungaria krt. 21. 


\section{MATERIALS AND METHODS}

\section{Strains}

The strains were the same as given earlier (Ernф \& Stipkovits 1973).

\section{Catabolism of carbohydrates and sugar alcohols}

Catabolism of glucose, mannose, galactose, saccharose, cellobiose, xylose, mannitol and sorbitol was examined. The basal medium $\left(b_{1}\right)$ employed was a modified standard growth medium (B), without yeast extract and with PPLO serum fraction replacing horse serum. The basal part, heart infusion broth (Difco), was treated with glucose oxidase, peroxidase and arginine decarboxylase to remove glucose and arginine (Sander 1972).

M e d i u m $b_{1}$

Heart infusion broth (Difco) * $120.0 \mathrm{ml}$

Sterilize by autoclaving

PPLO serum fraction (Difco)

$1.0 \mathrm{ml}$

Deoxyribonucleic acid **, $(0.2 \%(\mathrm{w} / \mathrm{v})$ solution)

$1.2 \mathrm{ml}$

Phenol red $(0.06 \%(\mathrm{w} / \mathrm{v})$ solution)

$5.0 \mathrm{ml}$

Thallium acetate $(10 \%(\mathrm{w} / \mathrm{v})$ solution)

$1.0 \mathrm{ml}$

Penicillin (200,000 i.u. per $\mathrm{ml})$

$0.25 \mathrm{ml}$

pH 7.8.

\section{Test media}

The test media ( $\mathrm{pH} 7.8$ ) were prepared by adding the following solutions to 1 lot $(128.45 \mathrm{ml})$ of medium $b_{1}$ :

$\begin{array}{ll}\text { Glucose }(50 \%(\mathrm{w} / \mathrm{v}) \text { solution }) & 1.6 \mathrm{ml} \\ \text { Mannose }(50 \%(\mathrm{w} / \mathrm{v}) \text { solution }) & 1.6 \mathrm{ml} \\ \text { Galactose }(25 \%(\mathrm{w} / \mathrm{v}) \text { solution }) & 3.2 \mathrm{ml} \\ \text { Saccharose }(50 \%(\mathrm{w} / \mathrm{v}) \text { solution }) & 1.6 \mathrm{ml} \\ \text { Cellobiose }(25 \%(\mathrm{w} / \mathrm{v}) \text { solution }) & 3.2 \mathrm{ml} \\ \text { Xylose }(50 \%(\mathrm{w} / \mathrm{v}) \text { solution }) & 1.6 \mathrm{ml} \\ \text { Mannitol }(25 \%(\mathrm{w} / \mathrm{v}) \text { solution }) & 3.2 \mathrm{ml} \\ \text { Sorbitol }(50 \%(\mathrm{w} / \mathrm{v}) \text { solution }) & 1.6 \mathrm{ml}\end{array}$

Test procedure. Medium $\mathrm{b}_{1}$ and test media were inoculated with single colonies. Inoculated and uninoculated media were incubated aerobically. Glucose breakdown was tested anaerobically too. Subcultivation in test media was performed twice, always during the late log. phase. Readings were done every second day for 2 weeks.

Interpretation. A color change from red to orange or lemoncolored indicated a positive reaction. The result was registered as negative though, if the same color change was seen in either $b_{1}$ medium or uninoculated test medium.

* Treated with enzymes.

* From calf thymus, Sigma Chemical Company, St. Louis, USA. 


\section{Catabolism of arginine}

The basal medium was $b_{2}$, being the same as $b_{1}$ except that $\mathrm{pH}$ was 7.3. The test medium was prepared by adding $4.25 \mathrm{ml}$ of $\mathrm{L}$-arginine $\left(30 \%(\mathrm{w} / \mathrm{v})\right.$ solution) to 1 lot $(128.45 \mathrm{ml})$ of medium $b_{2}$. The test procedure was the same as given above. A distinct alkaline color change, when compared with the pertinent control tubes, indicated a positive reaction.

\section{Phosphatase activity}

The following medium (Bph) was used:

$$
\text { M edium B ph }
$$

Heart infusion agar (Difco)

$74.0 \mathrm{ml}$

Sterilize by autoclaving

Horse serum (inactivated)

$20.0 \mathrm{ml}$

Yeast extract (Taylor-Robinson et al. 1963)

$5.0 \mathrm{ml}$

Sodium phenolphthalein diphosphate $(1 \%(\mathrm{w} / \mathrm{v})$ solution)

$1.0 \mathrm{ml}$

Penicillin (200,000 i.u. per $\mathrm{ml})$

$0.2 \mathrm{ml}$

Thallium acetate $(10 \%(\mathrm{w} / \mathrm{v})$ solution $)$

$0.8 \mathrm{ml}$ pH 7.8.

Uninoculated and inoculated plates were incubated in triplicate. After incubation for 3, 7 and 14 days, respectively, the plates were flooded with $2 \mathrm{ml}$ of $5 \mathrm{~N}-\mathrm{NaOH}$. Appearance of red color of the substrate, within $1 / 2$ min., indicated a positive reaction. As uninoculated plates turn red after some minutes, comparison is always necessary.

\section{"Film and spots" formation}

The "film and spots" phenomenon, described by Edward (1950) was detected by inoculating medium BY (Fabricant \& Freundt 1967). The plates were examined for production of "film and spots" after 3,7 and 14 days of incubation.

\section{M e di u m B Y}

Heart infusion agar (Difco)

Sterilize by autoclaving

Horse serum

Egg yolk emulsion *

Yeast extract (Taylor-Robinson et al.)

Deoxyribonucleic acid (Sigma $0.2 \%(\mathrm{w} / \mathrm{v})$ )

Penicillin (200,000 i.u. per $\mathrm{ml})$

Thallium acetate $(10 \%(\mathrm{w} / \mathrm{v})$ solution $)$

pH 7.8.
$90.0 \mathrm{ml}$

$20.0 \mathrm{ml}$

$13.6 \mathrm{ml}$

$10.0 \mathrm{ml}$

$1.2 \mathrm{ml}$

$0.25 \mathrm{ml}$

$1.0 \mathrm{ml}$

* The emulsion was prepared by mixing equal volumes of concentrated egg yolk emulsion (Difco) and $\mathrm{NaCl} 0.9 \%$. 


\section{Hydrolysis of aesculin}

The test was performed by inoculating aesculin plates $\left(A_{e}\right)$ with undiluted and $10^{-3}$ diluted stock cultures. The plates were examined every day for 14 days, and the appearance of brown or black coloration indicated a positive reaction.

\begin{tabular}{|c|c|}
\hline \multicolumn{2}{|l|}{ Medi u m $A_{e}$} \\
\hline Sterilize by autoclaving & \\
\hline Horse serum (inactivated) & 20.0 \\
\hline Yeast extract (Taylor-Robinson et al.) & 10.0 \\
\hline Aesculin (Merck) $(10 \%(\mathrm{w} / \mathrm{v})$ solution) & 1.2 \\
\hline Ferric citrate $(5 \%(\mathrm{w} / \mathrm{v})$ solution $)$ & 1.2 \\
\hline Thallium acetate $(10 \%(\mathrm{w} / \mathrm{v})$ solution $)$ & $1.0 \mathrm{ml}$ \\
\hline Penicillin $(200,000$ i.u. per $\mathrm{ml})$ & $0.25 \mathrm{ml}$ \\
\hline
\end{tabular}

\section{Hydrolysis of arbutin}

The test was performed by inoculating arbutin plates $\left(B_{\mathrm{ar}}\right)$ with undiluted and $10^{-3}$ diluted stock cultures, using the running drop technique; discs soaked with $0.02 \mathrm{ml} 5 \%(\mathrm{w} / \mathrm{v})$ solution of ferric citrate were placed in the middle of the inoculated area. The plates were examined every day for 14 days, and the appearance of brown or black coloration indicated a positive reaction.

Heart infusion agar (Difco)

$$
\text { M e d i u m } B_{\text {ar }}
$$

Sterilize by autoclaving

Horse serum (inactivated)

Yeast extract (Taylor-Robinson et al.)

Arbutin (Koch-Light Lab.) (10\% (w/v) solution)

Penicillin (200,000 i.u. per $\mathrm{ml})$

Thallium acetate $(10 \%(\mathrm{w} / \mathrm{v})$ solution $)$

pH 7.8.
$90.0 \mathrm{ml}$

$20.0 \mathrm{ml}$

$10.0 \mathrm{ml}$

$1.2 \mathrm{ml}$

$0.25 \mathrm{ml}$

$1.2 \mathrm{ml}$

\section{Hydrolysis of urea}

The test medium ( $\mathrm{pH} 7.3$ ) was prepared by adding $1.3 \mathrm{ml}$ of urea solution $40 \%(w / v)$ to 1 lot of medium $b_{2}$. Test procedure and interpretation as given under catabolism of arginine.

\section{Digestion of serum}

Undiluted and $10^{-3}$ dilutions of stock cultures were streaked onto slanted $S_{d}$ agar. The tubes were examined for liquefaction at frequent intervals during 14 days of incubation. 
Heart infusion broth (Difco)

M e d i u m $S_{d}$

Sterilize by autoclaving

Horse serum

Yeast extract (Taylor-Robinson et al.)

$8.0 \mathrm{ml}$

Sterile water

$30.0 \mathrm{ml}$

pH 7.8.

$0.8 \mathrm{ml}$

$1.2 \mathrm{ml}$

The medium was dispensed in $2 \mathrm{ml}$ volumes into screw cap tubes, and sterilized in a slanted position in flowing steam for $45 \mathrm{~min}$.

\section{Reduction of tetrazolium chloride}

The test was performed in rabbit meat infusion broth $\left(R_{t}\right)$ (Barber \& Fabricant 1971) using the same procedure as in testing of catabolism of carbohydrates. The development of a pink or red color with or without formation of a red precipitate indicates reduction of tetrazolium chloride to formazan, constituting a positive reaction.

Rabbit meat infusion

$$
\text { Medi u m } R_{t}
$$

Rabbit serum

$100.0 \mathrm{ml}$

Yeast extract (Taylor-Robinson et al.)

Deoxyribonucleic acid (Sigma $0.2 \%(\mathrm{w} / \mathrm{v})$ )

$10.0 \mathrm{ml}$

$10.0 \mathrm{ml}$

2,3,5, triphenyltetrazolium chloride (Merck)

$1.2 \mathrm{ml}$

Penicillin $(200,000$ i.u. per $\mathrm{ml})$

$$
(1 \%(\mathrm{w} / \mathrm{v}) \text { solution }) \quad 5.0 \mathrm{ml}
$$

Thallium acetate $(10 \%(\mathrm{w} / \mathrm{v})$ solution $)$

$0.25 \mathrm{ml}$

pH 7.8.

$1.0 \mathrm{ml}$

\section{Sensitivity to erythromycin, polymyxins and kanamycin}

The tests were performed as disc inhibition tests using the running drop technique. Sensitivity to erythromycin and polymyxins was tested with commercially available discs (A/S Rosco, 2630 Taastrup, Denmark), while kanamycin sensitivity was examined using discs (40 $\mu \mathrm{g}$ kanamycin sulphate/disc) prepared by Statens Seruminstitut, Copenhagen, Denmark.

\section{Hemolysis}

Examination of hemolytic activity was performed with the overlay technique (Clyde 1963) using calf, sheep and guinea-pig erythrocytes. Three to 4 days old colonies were overlaid with $2-3 \mathrm{ml}$ of a $5 \%$ suspension of erythrocytes in salt agar medium. The plates were read after $24 \mathrm{hrs}$. of incubation at $37^{\circ} \mathrm{C}$ and after a further incubation for 1 week at $22^{\circ} \mathrm{C}$.

\section{Hemadsorption}

Plates with 4 days old colonies, approx. 50 colonies per $\mathrm{cm}^{2}$, were overlaid with a $0.5 \%$ suspension of bovine and guinea-pig erythro- 
cytes in PBS (pH 7.2) (Manchee \& Taylor-Robinson 1968). The suspension was poured off after incubation for $1 / 2 \mathrm{hr}$. at $22^{\circ} \mathrm{C}$, and the plates were washed 5 times in PBS. The colonies were then examined for hemadsorption using a stereo microscope.

\section{Hemagglutination}

Four days old broth cultures were examined. The cultures were diluted $1: 2,1: 4$, and $1: 8$ in perspex agglutination trays, and to 0.25 $\mathrm{ml}$ of mycoplasma suspension was added $0.25 \mathrm{ml}$ of a $0.5 \%$ suspension of washed guinea-pig and calf erythrocytes. The plates were read when controls consisting of erythrocytes suspended in sterile broth had sedimented.

\section{Polyacrylamide gel electrophoresis}

The procedure described by Rottem \& Razin (1967) was followed without modifications. Concentrated and washed cells were solubilized in phenol-acetic-water $(2: 1: 0.5, \mathrm{w} / \mathrm{v} / \mathrm{v})$ and run in polyacrylamide gels containing $5 \mathrm{M}$ urea and $35 \%$ acetic acid.

\section{Carotenoid synthesis}

The ability of Acholeplasma strains to synthesize carotenoid pigments was tested according to the procedure of Razin \& Cleverdon (1965). The absorption spectrum was determined at wave lengths between 350 and $550 \mathrm{~nm}$.

Special methods for $M$. dispar and strain $M 165 / 69$

As M. dispar will not grow in media without serum the investigations on catabolism were carried out by inoculating test media with $0.1 \mathrm{ml}$ of a concentrated $(20 \mathrm{x})$ and washed suspension of organisms. All other biochemical tests were performed using FF II and GS as basal media, replacing the standard growth medium (Ern $\varnothing$ \& Stipkovits).

Since strain M165/69 also proved to grow poorly in the test media for catabolism the standard method was supplemented by inoculation of a suspension of organisms as described for M. dispar.

\section{Biochemical tests}

\section{RESULTS AND DISCUSSION}

All strains were urea, saccharose, and mannitol negative. The results of the other biochemical tests are summarized in Table 1. In routine diagnostic work the following tests would appear to be appropriate for strains shown to be resistant to digitonin (genus Acholeplasma): catabolism of galactose, xylose, aesculin and arbutin (Table 2). If a given strain is shown to be digitonin sensitive (genus Mycoplasma) the following tests are useful for 


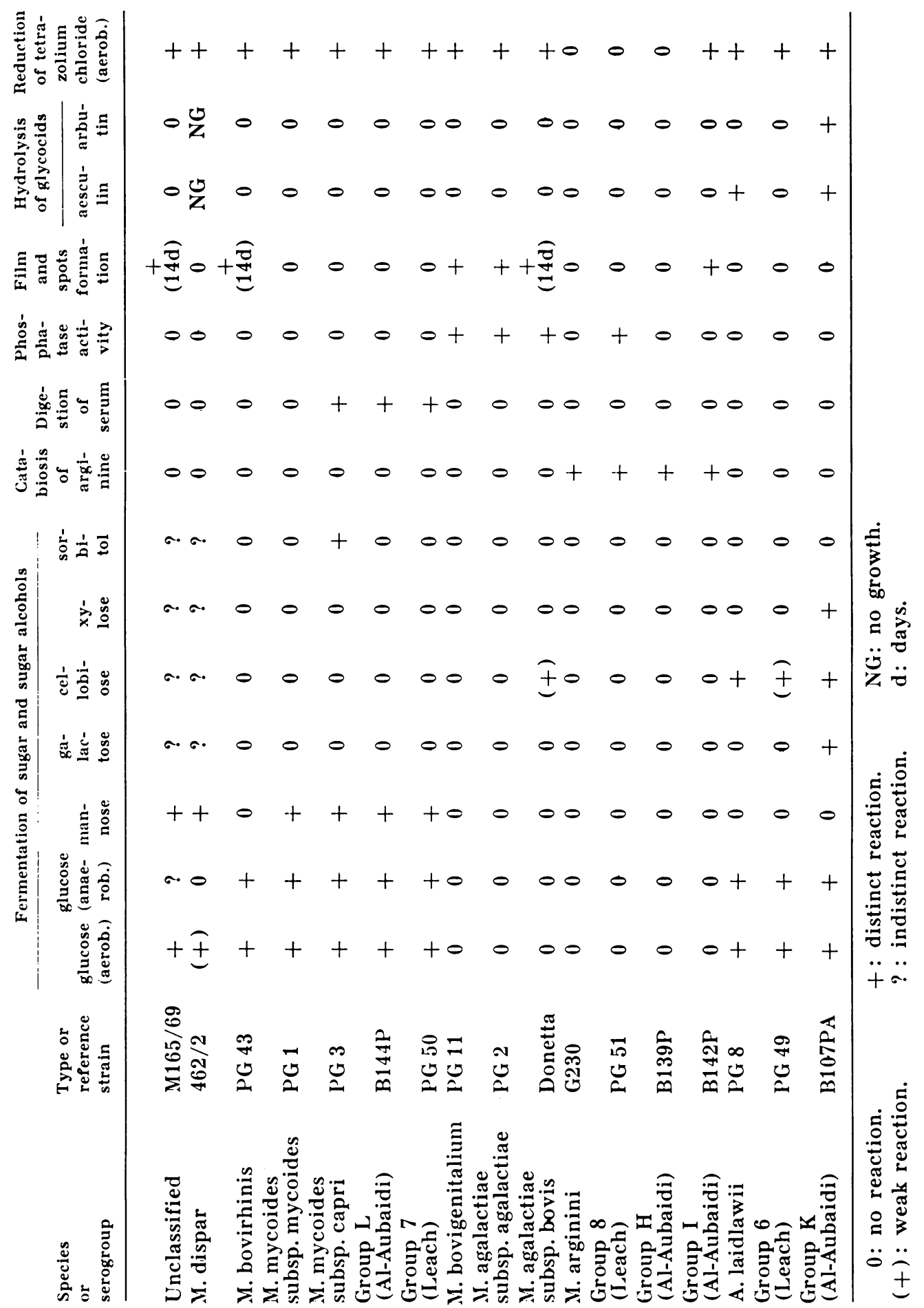


T a b l e 2. Acholeplasma. Diagnostic biochemical reactions.

\begin{tabular}{lcccc}
\hline Species or serogroup & Galactose & xylose & Aesculin & Arbutin \\
\hline A. laidlawii (PG 8) & 0 & 0 & + & 0 \\
Group 6 (PG 49) & 0 & 0 & 0 & 0 \\
Group K (B 107 PA) & + & + & + & + \\
\hline
\end{tabular}

further differentiation: catabolism of glucose and arginine, phosphatase activity, "film and spots" formation and digestion of serum (Table 3 ). The first 2 methods subdivide genus Mycoplasma into 3 groups (Table 3). (1) Glucose positive and arginine negative: M. mycoides subsp. mycoides, M. mycoides subsp. capri, group L, group 7, M. dispar, M. bovirhinis, and strain M165/69. (2) Glucose and arginine negative: M. bovigenitalium and both varieties of $M$. agalactiae. (3) Arginine positive and glucose negative: $M$. arginini, group $H$, group 8 and group $I$. Within these 3 groups serologic examinations should be performed to make

T a b le 3. Mycoplasma. Diagnostic biochemical reactions.

\begin{tabular}{|c|c|c|c|c|c|}
\hline $\begin{array}{l}\text { Species or } \\
\text { serogroup }\end{array}$ & Glucose & Arginine & Phosphatase & $\begin{array}{l}\text { Film and } \\
\text { spots }\end{array}$ & $\begin{array}{c}\text { Serum } \\
\text { digestion }\end{array}$ \\
\hline $\begin{array}{l}\text { M. mycoides } \\
\text { subsp. mycoides }\end{array}$ & + & 0 & 0 & 0 & 0 \\
\hline $\begin{array}{l}\text { M. bovirhinis, } \\
\text { strain M165/69 }\end{array}$ & + & 0 & 0 & $(+)$ & 0 \\
\hline $\begin{array}{l}\text { M. mycoides } \\
\text { subsp. capri, } \\
\text { Group L, } \\
\text { Group } 7\end{array}$ & + & 0 & 0 & 0 & + \\
\hline $\begin{array}{l}\text { M. bovigenitalium, } \\
\text { M. agalactiae } \\
\text { subsp. agalactiae, } \\
\text { M. agalactiae } \\
\text { subsp. bovis }\end{array}$ & 0 & 0 & + & + & 0 \\
\hline $\begin{array}{l}\text { M. arginini, } \\
\text { Group } H\end{array}$ & 0 & + & 0 & 0 & 0 \\
\hline Group 8 & 0 & + & + & 0 & 0 \\
\hline Group I & 0 & + & 0 & + & 0 \\
\hline
\end{tabular}

$(+)$ : Positive after 14 days of incubation. 
a final diagnosis, although the phosphatase test, "film and spots" formation and serum digestion to some degree may limit the number of tests required. Of special interest is the fact that the representative strains of group $\mathrm{L}$ and group 7 digested serum, a property otherwise characteristic for some strains of both varieties of M. mycoides. It was reported by Aluotto et al. (1970) that M. bovirhinis was serum digestion positive too, but we were unable to confirm this finding. M. dispar and strain M165/69 were gluoose and mannose positive, reduced tetrazolium chloride while all other tests were negative or indistinct. Biochemical investigations are especially difficult with $M$. dispar because of the particular growth requirements which on the other hand in themselves are suggestive of the diagnosis. Therefore a preliminary diagnosis based on the growth requirements may be confirmed serologically without biochemical testings. Certain complications appeared in regard to $\mathrm{M165/69}$ too. This strain is acid producing and some of the acid production is not due to catabolism of glucose. This makes it difficult to decide, under the given conditions, whether M165/69 is able to catabolize arginine as well. In some of the experiments it seemed to be so, but strain M165/69 is nevertheless referred to as being arginine negative until more refined methods have proven the ability of arginine decarboxylation.

\section{Sensitivity to erythromycin, kanamycin and polymyxins}

As it appears from Table 4, all strains were sensitive to kanamycin, 15 strains were sensitive to erythromycin and 7 strains were sensitive to polymyxins. It is not passible, on the basis of this investigation, to determine whether sensitivity tests may be of diagnostic value, as it particularly in this area is necessary to examine a greater number of strains. Results from different laboratories are often difficult to compare beoause of differences in performance of the tests. Comparing our results with the work of Al-Aubaidi \& Fabricant* (1971) great discrepancies are seen, in particular with respect to kanamycin to which all strains were insensitive according to these authors.

* These apparent discrepancies were later found to be due to an error in the table, and the actual results were identical to those reported in the present paper (Personal communication from J. Fabricant 1973). 
T a ble 4. Bovine mycoplasmas: Sensitivity to antibiotics.

\begin{tabular}{|c|c|c|c|c|}
\hline \multirow{2}{*}{$\begin{array}{l}\text { Species } \\
\text { or } \\
\text { serogroup }\end{array}$} & \multirow{2}{*}{$\begin{array}{l}\text { Type or } \\
\text { reference } \\
\text { strain }\end{array}$} & \multicolumn{3}{|c|}{ Inhibition zone in $\mathrm{mm}$} \\
\hline & & $\begin{array}{l}\text { erythro- } \\
\text { mycin }\end{array}$ & $\begin{array}{l}\text { kana- } \\
\text { mycin }\end{array}$ & $\begin{array}{l}\text { poly- } \\
\text { myxins }\end{array}$ \\
\hline Unclassified & M165/69 & 8.0 & 25.0 & 5.0 \\
\hline M. dispar & $462 / 2$ & 12.0 & 25.0 & 10.0 \\
\hline M. bovirhinis & PG 43 & 7.0 & 18.0 & 4.0 \\
\hline $\begin{array}{l}\text { M. mycoides } \\
\text { subsp. mycoides }\end{array}$ & PG 1 & 30.0 & 11.0 & 0 \\
\hline $\begin{array}{l}\text { M. mycoides } \\
\text { subsp. capri }\end{array}$ & PG 3 & 30.0 & $\begin{array}{l}1.0 \\
\text { (p.i.) }\end{array}$ & 0 \\
\hline $\begin{array}{l}\text { Group L } L \\
\text { (Al-Aubaidi) }\end{array}$ & B144P & 30.0 & 5.0 & 0 \\
\hline $\begin{array}{l}\text { Group } 7 \\
\text { (Leach) }\end{array}$ & PG 50 & 22.0 & 9.0 & 0 \\
\hline M. bovigenitalium & PG 11 & 30.0 & 7.0 & 1.5 \\
\hline $\begin{array}{l}\text { M. agalactiae } \\
\text { subsp. agalactiae }\end{array}$ & PG 2 & 10.0 & 12.0 & 7.0 \\
\hline $\begin{array}{l}\text { M. agalactiae } \\
\text { subsp. bovis }\end{array}$ & Donetta & 7.0 & 10.0 & 0 \\
\hline M. arginini & G230 & $\mathbf{0}$ & 10.0 & 0 \\
\hline $\begin{array}{l}\text { Group } 8 \\
\text { (Leach) }\end{array}$ & PG 51 & 0 & 4.0 & 0 \\
\hline$\underset{\text { (Al-Aubaidi) }}{\text { Group }}$ & B139P & 7.0 & 19.0 & 3.0 \\
\hline $\begin{array}{l}\text { Group I } \\
\text { (Al-Aubaidi) }\end{array}$ & B142P & 10.0 & 4.0 & 0 \\
\hline A. laidlawii & PG 8 & 20.0 & 10.0 & 0 \\
\hline $\begin{array}{l}\text { Group } 6 \\
\text { (Leach) }\end{array}$ & PG 49 & 15.0 & 18.0 & 15.0 \\
\hline$\underset{\text { (Al-Aubaidi) }}{\text { Group } K}$ & B107PA & 22.0 & 16.0 & 0 \\
\hline
\end{tabular}

p. i.: partial inhibition.

Hemadsorption, hemagglutination and hemolysis (Table 5)

Only 2 strains were found to hemadsorb, viz. M165/69 and PG 2 (M. agalactiae subsp. agalactiae). This is a clear example to illustrate the necessity of examining several strains in regard to at least some characters, as it was found by Mensik \& Jurmanova (1970) that all strains of $M$. bovirhinis isolated in Czechoslovakia were able to hemadsorb; in our experiments the type strain of this species was hemadsorption negative.

Eleven strains agglutinated guinea-pig erythrocytes, none ag- 
Table 5. Bovine mycoplasmas: Hemadsorption, hemagglutination and hemolysis.

\begin{tabular}{|c|c|c|c|c|c|c|c|c|}
\hline \multirow[b]{2}{*}{$\begin{array}{l}\text { Species } \\
\text { or } \\
\text { serogroup }\end{array}$} & \multirow[b]{2}{*}{$\begin{array}{l}\text { Type or } \\
\text { reference } \\
\text { strain }\end{array}$} & \multicolumn{2}{|c|}{ Hemadsorption } & \multicolumn{2}{|c|}{ Hemagglutination } & \multicolumn{3}{|c|}{ Hemolysis } \\
\hline & & $\begin{array}{l}\text { guinea- } \\
\text { pig ery- } \\
\text { throcytes }\end{array}$ & $\begin{array}{l}\text { hovine } \\
\text { erythro- } \\
\text { cytes }\end{array}$ & $\begin{array}{l}\text { guinea- } \\
\text { pig ery- } \\
\text { throcytes }\end{array}$ & $\begin{array}{l}\text { bovine } \\
\text { erythro- } \\
\text { cytes }\end{array}$ & $\begin{array}{l}\text { guinea- } \\
\text { pig ery- } \\
\text { throcytes }\end{array}$ & $\begin{array}{l}\text { bovine } \\
\text { erythro- } \\
\text { cytes }\end{array}$ & $\begin{array}{l}\text { ovine } \\
\text { erythro- } \\
\text { cytes }\end{array}$ \\
\hline Unclassified & M165/69 & + & + & 0 & 0 & $\alpha$ & $\alpha(\beta)$ & $\alpha(\beta)$ \\
\hline M. dispar & $462 / 2$ & 0 & 0 & 0 & 0 & $\alpha$ & $\alpha(\alpha)$ & $\alpha(\beta)$ \\
\hline M. bovirhinis & PG 43 & 0 & 0 & + & 0 & $\beta$ & $\alpha(\alpha)$ & $\alpha(\beta)$ \\
\hline $\begin{array}{l}\text { M. mycoides } \\
\text { subsp. mycoides }\end{array}$ & PG 1 & 0 & 0 & + & 0 & $\beta$ & $\alpha(\beta)$ & $\alpha(\beta)$ \\
\hline $\begin{array}{l}\text { M. mycoides } \\
\text { subsp. capri }\end{array}$ & PG 3 & 0 & 0 & + & 0 & $\beta$ & $\alpha(\beta)$ & $\alpha(\beta)$ \\
\hline $\begin{array}{l}\text { Group I } \\
\text { (Al-Aubaidi) }\end{array}$ & B144P & 0 & 0 & + & 0 & $\beta$ & $\alpha(\alpha)$ & $\alpha(\alpha)$ \\
\hline $\begin{array}{l}\text { Group } 7 \\
\text { (Leach) }\end{array}$ & PG 50 & 0 & 0 & + & 0 & $\beta$ & $\alpha(\beta)$ & $\alpha(\alpha)$ \\
\hline M. bovigenitalium & PG 11 & 0 & 0 & 0 & 0 & $\beta$ & $\alpha(\beta)$ & $\alpha(\beta)$ \\
\hline $\begin{array}{l}\text { M. agalactiae } \\
\text { subsp. agalactiae }\end{array}$ & PG 2 & + & + & 0 & 0 & $\beta$ & $\alpha(\beta)$ & $\alpha(\beta)$ \\
\hline $\begin{array}{l}\text { M. agalactiae } \\
\text { subsp. bovis }\end{array}$ & Donetta & 0 & 0 & + & 0 & $\beta$ & $\alpha(\alpha)$ & $\alpha(\beta)$ \\
\hline M. arginini & G 230 & 0 & 0 & 0 & 0 & $\alpha$ & $\alpha(\alpha)$ & $\alpha(\beta)$ \\
\hline $\begin{array}{l}\text { Group } 8 \\
\text { (Leach) }\end{array}$ & PG 51 & 0 & 0 & + & 0 & $\alpha$ & $\alpha(\beta)$ & $\alpha(\alpha)$ \\
\hline $\begin{array}{l}\text { Group } \mathrm{H} \\
\text { (Al-Aubaidi) }\end{array}$ & B139P & 0 & 0 & 0 & 0 & $\alpha$ & $\alpha(\beta)$ & $\alpha(\alpha)$ \\
\hline $\begin{array}{l}\text { Group I } \\
\text { (Al-Aubaidi) }\end{array}$ & $\mathrm{B} 142 \mathrm{P}$ & 0 & 0 & + & 0 & $\alpha$ & $\alpha(\beta)$ & $\alpha(\beta)$ \\
\hline A. laidlawii & PG 8 & 0 & 0 & + & 0 & $\beta$ & $\alpha(\beta)$ & $\alpha(\beta)$ \\
\hline $\begin{array}{l}\text { Group } 6 \\
\text { (Leach) }\end{array}$ & PG 49 & 0 & 0 & + & 0 & $\beta$ & $\alpha(\beta)$ & $\alpha(\beta)$ \\
\hline $\begin{array}{l}\text { Group K } \\
\text { (Al-Aubaidi) }\end{array}$ & B107PA & 0 & 0 & + & 0 & $\beta$ & $\alpha(\alpha)$ & $\alpha(\alpha)$ \\
\hline
\end{tabular}

In parantheses: Results after further incubation for 1 week at room temperature.

glutinated bovine erythrocytes. Guinea-pig erythrocytes were also more useful in the hemolysis experiments as all arginine positive strains were $\alpha$-hemolytic, while all glucose positive strains were $\beta$-hemolytic, except M. dispar and strain M165/69. Using bovine and ovine erythrocytes all strains were $\alpha$-hemolytic after primary incubation for $24 \mathrm{hrs}$. at $37^{\circ} \mathrm{C}$; after further incubation for 1 week at $22^{\circ} \mathrm{C}$ some strains showed $\beta$-hemolysis. 
Electrophoresis. The electrophoretic pattern of all strains differed from each other. The results do not add further to the current discussion whether PG 1 and PG 3 should be regarded as variants of the same species, $M$. mycoides, or rather as representatives of 2 distinct species (Edward \& Freundt 1969). The same considerations hold true for $P G 2$ and Donetta, the type strains of the 2 subspecies of $M$. agalactiae. It is evident that great experience is required in electrophoresis, both regarding technique and width of examined material. If these conditions are not fulfilled it is impossible to settle the very relevant question whether differences in electrophoretic patterns between 2 species always may be distinguished from variations between different strains of the same species.

\section{Carotenoid determinations *}

Carotenoids were, in agreement with Rothblat \& Smith (1961), found to be synthesized by $A$. laidlawii while the representative strains of serogroup $K$ and serogroup 6 did not synthesize carotenoid pigments.

\section{CONCLUSIONS}

It is concluded that all biological and biochemical tests required by the Subcommittee on the Taxonomy of Mycoplasmatales (Subcommittee 1972) may be accomplished in an ordinary laboratory and that the difficulties are no greater than in some bacteriological work. The necessity of having media controls including both basal substrates and test substrates, should be emphasized.

For diagnostic purposes all the tests described above are, of course, not required. It is recommended to test initially for sensitivity to digitonin. Subsequently any digitonin resistant strains (genus Acholeplasma) should be examined for ability to catabolize galactose, xylose, aesculin and arbutin. If a strain belongs to genus Mycoplasma (digitonin sensitive), the following tests should be performed: catabolism of glucose and arginine, phosphatase activity, "film and spots" formation and digestion of serum. These biochemical tests will reduce the amount of serologic work required for final identification, and the results will in themselves support the final diagnosis.

* We are indebted to Kurt Berg, M.Sc., for performing the carotenoid determinations. 


\section{REFERENCES}

Al-Aubaidi, J. M. \& J. Fabricant: Characterization and classification of bovine mycoplasma. Cornell Vet. 1971, 61, 490-5i8.

Aluotto, B. B., R. G. Wittler, C. O. Williams \& J. E. Faber: Standardized bacteriologic techniques for the characterization of Myciplasma species. Int. J. system. Bact. 1970, 20, 35-58.

Barber, T. L. \& J. Fabricant: Identification of Mycoplasmatales: Characterization procedures. Appl. Microbiol. 1971, 21, 600-605.

Clyde, W. A.: Hemolysis in identifying Eatons' pleuropneumonia-like organism. Science 1963, 139, 55.

Edwards, D. G. ff.: An investigation of the biological properties of organisms of the pleuropneumonia group, with suggestions regarding the identification of strains. J. gen. Microbiol. 1950, 4, $311-329$.

Edward, D. G. ff. \& E. A. Freundt: Classification of the Mycoplasmatales. In The Mycoplasmatales and the L-phase of Bacteria. L. Hayflick ed., Appleton-Century-Crofts, New York 1969, 187190.

Ernф, H. \& L. Stipkovits: Bovine mycoplasmas: Cultural and biochemical studies. I. Acta vet. scand. 1973, 14, 436-449.

Fabricant, J. \& E. A. Frenndt: Importance of extension and standardization of laboratory tests for the identification and classification of mycoplasma. Ann. N.Y. Acad. Sci. 1967, 143, 50-58.

Manchee, R. J. \& D. Taylor-Robinson: Hemadsorption and hemagglutination by mycoplasmas. J. gen. Microbiol. 1968, 50, 465-478.

Mensik, J. \& K. Jurmanova: Occurrence of Mycoplasma bovirhinis in connection with pneumonia of calves. Abstr. Xth Conf. Tax. Bact. Mycopl., Brno 1970, 10-11.

Razin, S. \& R. C. Cleverdon: Carotenoids and cholesterol in membranes of Mycoplasma laidlawii. J. gen. Microbiol. 1965, 41, $409-415$.

Rothblat, G. H. \& P. F. Smith: Nonsaponifiable lipids of representative pleuropneumonia-like organisms. J. Bact. 1961, 82, 479491.

Rottem, S. \& S. Razin: Electrophoretic patterns of membrane proteins of mycoplasma. J. Bact. 1967, 9/, 359-364.

Sander, T.: Perssinal communication 1972.

Subcommittee on the Taxonomy of Mycoplasmatales: Proposal for minimal standards for descriptions of new species of the order Mycoplasmatales. Int. J. system. Bact. 1972, 22, 184-188.

Taylor-Robinson, D., N. L. Somerson, H. C. Turner \& R. M. Chanock: Serological relationships among human mycoplasmas as shown by complement-fixation and gel diffusion. J. Bact. 1963, 85, $1261-1273$. 


\section{SAMMENDRAG}

Bovine mykoplasmer: Dyrkningsmæssige og biokemiske undersøgelser. II.

Referencestammer for de for tiden kendte bovine mykoplasmaarter eller serogrupper er unders $\varnothing$ gt ved en række biokemiske og biologiske tests. Formålet med disse undersøgelser var dels at opfylde de krav, som er opstillet af "The Subcommittee on the Taxonomy of Mycoplasmatales“ ved beskrivelse af nye arter, og dels at udvælge metoder, som er af værdi i det daglige diagnostiske arbejde. I relation til det sidste punkt anbefales følgende unders $\emptyset$ gelser for stammer tilhørende slægten Acholeplasma, som er digitonin resistent: Katabolisme af galaktose, xylose, aesculin og arbutin. For genus Mycoplasma, som er digitonin følsom, er følgende 5 prøver af særlig værdi: Katabolisme af glukose og arginin, phosphataseaktivitet, dannelse af "film and spots" og serumspaltning.

(Received November 23, 1972).

Reprints may be requested from: H. Ern $\varnothing$, Institute of Medical Microbiology, University of Aarhus, DK-Aarhus C, Denmark. 